\title{
Growth performance and safety of meat from cattle feedlot finished with monensin in the ration
}

\author{
Desempenho produtivo e inocuidade da carne de bovinos \\ terminados em confinamento com monensina na ração
}

\author{
Mikael Neumann ${ }^{1}$; Robson Kyoshi Ueno ${ }^{2}$; Julio Cezar Heker Junior ${ }^{3 *}$; Eloize \\ Jaqueline Askel ${ }^{4}$; André Martins de Souza ${ }^{4}$; Gabriela Letícia Delai Vigne ${ }^{5}$; Milaine \\ Poczynek $^{6}$; Marina Gavanski Coelho ${ }^{6}$; Augusto Kendi Eto ${ }^{7}$
}

\begin{abstract}
Monensin is an ionophore antibiotic, the inclusion of which in the feed of beef cattle favors the best use of feed nutrients, via ruminal modulation. However, there are concerns regarding the residence of residues in the carcass from metabolism of monensin. The objective of this study was to evaluate the productive performance, carcass characteristics, serum parameters, tissue residual depletion and economic benefit of finishing of young bulls in confinement with monensin in the ration. Thirtysix animals were confined, and given 50\% corn silage feed and 50\% more concentrated feed. The experimental design was completely randomized, with two treatments (with or without monensin) and 10 replicates for the control group and eight for the monensin group. The use of monensin reduced the dry matter intake in relation to live weight (2.36\% vs 2.55\%), and improved feed conversion ( 8.61 vs $10.06 \mathrm{~kg} \mathrm{~kg}^{-1}$ ); the animals presented higher live weight (511 vs $494 \mathrm{~kg}$ ), higher warm carcass weight (285 vs $272 \mathrm{~kg}$ ) and an increase in fat thickness (4.97 vs $4.25 \mathrm{~mm}$ ) compared to control animals. These increases in performance gave higher economic results, with a profit margin of $\mathrm{R} \$ 122.84$ per animal. A waiting period of $16 \mathrm{~h}$ before slaughter resulted in monensin concentrations below $0.25 \mu \mathrm{g} \mathrm{kg}^{-1}$ in edible organs and tissues, values well below those permitted by legislation. The use of monensin for young bulls in confinement promoted improvements in productive and economic performance, without leaving residues in edible tissues.
\end{abstract}

Key words: Feed conversion. Growth promoter additive. Ionophores. Waiting period.

${ }_{1}$ Eng $^{\circ}$ Agr $^{\circ}$, Prof. Dr., Programa de Pós-Graduação em Produção Vegetal, Universidade Estadual do Centro-Oeste, UNICENTRO, Guarapuava, PR, Brasil. E-mail: neumann.mikael@hotmail.com

2 Médico Veterinário, Prof. Dr., Curso de Medicina Veterinária, Faculdade Guarapuava, Guarapuava, PR, Brasil. E-mail: robsonueno@hotmail.com

3 Médico Veterinário, M.e, Discente, Curso de Doutorado do Programa de Pós-Graduação em Produção Vegetal, UNICENTRO, Guarapuava, PR, Brasil. E-mail: jr_heker@hotmail.com

4 Discentes, Curso de Medicina Veterinária, UNICENTRO, Guarapuava, PR, Brasil. E-mail: elojaque@gmail.com; andrems_92@ hotmail.com

5 Médica Veterinária, Discente de Mestrado, Programa de Pós-Graduação em Ciências Veterinárias, UNICENTRO, Guarapuava, PR, Brasil. E-mail: gabivigne@hotmail.com

6 Médicas Veterinárias, Discentes de Mestrado em Ciência Animal e Pastagens, Escola Superior de Agricultura "Luiz de Queiroz", ESALQ/USP, Piracicaba, SP, Brasil. E-mail: milainepoc@gmail.com; mariinagcoelho@gmail.com

7 Auxiliar de Pesquisa e Desenvolvimento, Impextraco Latin America Ltda. Curitiba, PR, Brasil. E-mail: augusto@impextraco. com.br

* Author for correspondence

Received: Mar. 09, 2017 - Approved: Nov. 24, 2017 


\section{Resumo}

A monensina é um antibiótico ionóforo, cuja inclusão na alimentação de bovinos de corte favorece o melhor aproveitamento dos nutrientes da ração, via modulação ruminal. Porém há preocupações no que tange a permanência de resíduos na carcaça, provenientes da metabolização da monensina. Assim, objetivou-se avaliar o desempenho produtivo, as características de carcaça, os parâmetros séricos, a depleção residual tecidual e a economicidade da terminação de tourinhos em confinamento com monensina na ração. Foram confinados 36 animais com ração $50 \%$ de silagem de milho mais $50 \%$ concentrado. $\mathrm{O}$ delineamento experimental foi inteiramente casualizado, com 2 tratamentos (com ou sem monensina) e 10 repetições para o grupo controle e 8 para o grupo com monensina. $\mathrm{O}$ uso de monensina reduziu o consumo de matéria seca em relação ao peso vivo (2,36 vs 2,55\%), melhorou a conversão alimentar $\left(8,61\right.$ vs 10,06 $\left.\mathrm{kg} \mathrm{kg}^{-1}\right)$, os animais apresentaram maior peso vivo (511 vs 494 $\mathrm{kg})$, maior peso de carcaça quente $(285$ vs $272 \mathrm{~kg}$ ) e aumento na espessura de gordura (4,97 vs 4,25 $\mathrm{mm}$ ) comparativamente aos animais da ração controle. Tais acréscimos em desempenho conferiram maiores resultados econômicos, com margem de lucro de $\mathrm{R} \$ 122,84$ por animal. O período de carência de 16 horas antes do abate apresentou concentrações de monensina inferiores a $0,25 \mu \mathrm{g} \mathrm{kg}^{-1}$ nos órgãos e tecidos comestíveis, valores muito abaixo dos permitidos na legislação. $\mathrm{O}$ uso de monensina para tourinhos em confinamento promoveu melhorias no desempenho produtivo e econômico, sem deixar resíduos nos tecidos comestíveis.

Palavras-chave: Aditivo promotor de crescimento. Conversão alimentar. Ionóforos. Período de carência.

\section{Introduction}

Efficiency in beef cattle is increasingly needed, taking into account the growing demand for food and meat of good quality by consumers, and the sustainability of production systems. With these arguments, there is support for intensive production systems that exploit the productive potential of superior animals through quality nutrition, aiming at the greater and better use of the nutrients and energy provided via feed, and maximum performance.

In this context the importance of food additives, which act as performance enhancers for beef cattle, is mentioned. According to Millen et al. (2009), 98.7\% of the Brazilian feedlots attended by nutritionists interviewed in their research use feed additives in the feed. Sodium monensin is a food additive in the ionophore group, an ingredient in commercial diets for beef and dairy cattle.

Sodium monensin is produced by the fermentation of Streptomyces cinnamonensis, and it promotes the ionic destabilization of Gram-positive bacteria by means of the flow of $\mathrm{Na}^{+}$ions into the cell, compromising the osmotic and electrolytic balance of the microorganisms. In the rumen environment, it will act on lactic acid bacteria (Streptococcus bovis and Lactobacillus spp.), reducing the incidence of metabolic and ruminal diseases, such as lactic acidosis (NOGUEIRA et al., 2009; RANGEL et al., 2008; ZANINE et al., 2006), caused by a high proportion of concentrate in the feed, and favoring a reduction in methane production by the reduction of Gram-positive bacteria that have hydrogen as the final product (KOBAYASHI, 2010; RANGEL et al., 2008).

Thus, there is an increase in the participation of Gram-negative bacteria, such as propionate producers and lactate users, in the rumen, considering that propionate is the most efficient source of energy for ruminants during ruminal fermentation. Concomitantly, there is a decrease in the acetate:propionate relation in the rumen, increasing the metabolizable energy due to a reduction in acetate production (PRADO et al., 2010). There is greater availability of food-derived protein in the small intestine, due to a decrease in proteolytic and fermentative amino acid bacteria, favoring protein metabolism (RANGEL et al., 2008). 
Despite the evident benefits, in the European Union, the use of antibiotics as growth promoters in feed has been associated with resistance to antibiotics in humans who consume the products and co-products of these animals, presumably due to the presence of residual residues, and has been banned since 2006 (GATTÁS et al., 2008). However, according to Russell and Houlihan (2003), the resistance of humans to antibiotics is not linked to resistance to ionophores in ruminants, since they are not used for treatment of human diseases.

Given the significance of monensin sodium as an additive in ruminant feed, the objective of the present study was to verify the productive performance of young bulls fed with or without the inclusion of monensin sodium in the feed, and to verify the level of residual depletion at slaughter, for different periods of ionophore deficiency, in order to confirm the safety of food for consumers.

Materials and Methods

The work was carried out at the Animal Production Center (NUPRAN) of the State University of the Central-West, in Guarapuava, Paraná, Brazil. Thirty-six crossbred Angus $\times$ Canchim young bulls were used, with an average age of 10 months and an initial average weight of $377 \mathrm{~kg}$. The treatments consisted of the supply of a feed made of $50 \%$ corn silage and $50 \%$ concentrate on a dry basis, with ionophore (sodium monensin) or without ionophore (control).

The ionophore tested was monensin sodium (Rumimpex ${ }^{\circledR}$, Impextraco Latin America Ltda.), at a dosage of $1.25 \mathrm{~g} \mathrm{animal}^{-1} \mathrm{day}^{-1}$, enough to provide $250 \mathrm{mg}$ animal $^{-1}$ day $^{-1}$ of monensin.
The animals were housed in 18 semi-covered confinement stables, each with an area of $15 \mathrm{~m}^{2}$, a concrete feeder and a water tank regulated by a float. Each stable with two animals was considered an experimental unit. Confinement lasted 94 days, with the initial 10 days for adaptation and three sequential periods of 28 days for evaluation. The animals were weighed at the beginning and at the end of each period, after $12 \mathrm{~h}$ of solids fasting. Food management was performed twice a day at $06 \mathrm{~h} 00$ and at $17 \mathrm{~h} 00$. Adjustment in the supply was made daily, in order to offer food ad libitum, considering leftovers of $5 \%$ of dry matter (DM).

The feed was formulated to provide a gain of $1.5 \mathrm{~kg}$ of animal live weight day ${ }^{-1}$ (NRC, 2000). Food was supplied as fully mixed feed (TMR), and monensin was offered in TMR in order to guarantee total ingestion. The feed consisted of $50 \%$ corn silage and $50 \%$ concentrate. In preparation of the concentrate, the following foods were used: ground corn $(70 \%)$ with a commercial protein core $(30 \%)$ composed of soybean meal, soybean hull, barley radish, ground corn kernels, calcitic limestone, dicalcium phosphate, common salt, livestock urea and vitamin and mineral premix.

Samples of the rations and leftovers were collected during the experiment. Crude protein $(\mathrm{CP})$, mineral matter (MM), ethereal extract (EE), neutral detergent fiber (NDF) with thermostable $\alpha$-amylase enzyme and acid detergent fiber (ADF) in the samples was determined according to Silva and Queiroz (2009). The total digestible nutrient content (TDN) was calculated according to the equations proposed by Weiss et al. (1992). The results of the analyses are shown in Table 1. 
Table 1. Bromatological analysis of foods and experimental feed.

\begin{tabular}{lcccc}
\hline \multicolumn{1}{c}{ Parameter } & Corn silage & Corn kernel & Protein concentrate & Feed $^{1}$ \\
\hline Dry matter content, \% & 37.35 & 90.03 & 89.99 & 63.68 \\
Mineral matter (\% MS) & 2.42 & 0.76 & 21.03 & 4.63 \\
Crude protein (\% MS) & 5.91 & 7.60 & 42.71 & 12.02 \\
Ethereal extract (\% MS) & 3.03 & 3.73 & 2.34 & 3.17 \\
Neutral detergent fiber (\% MS) & 53.61 & 17.13 & 22.85 & 36.23 \\
Fiber in acid detergent (\% MS) & 29.04 & 5.93 & 10.77 & 18.21 \\
Total digestible nutrients (\% MS) & 67.51 & 83.69 & 69.70 & 73.50 \\
\hline
\end{tabular}

${ }^{1}$ Composition: $50 \%$ corn silage $+35 \%$ ground corn kernel $+15 \%$ protein nucleus.

Estimated total digestible nutrients according to Weiss et al. (1992), by equation NDT $(\% \mathrm{MS})=\mathrm{CNFvd}+\mathrm{PBvd}+(\mathrm{EE}-10) \times$ $2.25+$ FDNvd $-70(\mathrm{CNFvd}=$ truly digestible non-fibrous carbohydrates; PBvd $=$ truly digestible crude protein; FDNvd $=$ truly digestible neutral detergent fiber; and $70=$ discount constant of fecal metabolic constituents).

In evaluation of productive performance during confinement, daily dry matter intake (DMI), consumption expressed as a percentage of the live weight (PDMI), average daily weight gain (ADG) and feed conversion ratio (FC) were measured.

On days $0,28,56$ and 84, blood samples were collected to evaluate the serum biochemical profile of liver and renal function indicators. A sample of $20 \mathrm{~mL}$ of blood from one animal was collected per experimental unit, $10 \mathrm{~mL}$ of which was stored in a heparin sodium anticoagulant tube for quantification of fibrinogen, and $10 \mathrm{~mL}$ stored in tubes for the quantification of gamma glutamyl transferase (GGT) and aspartate aminotransferase (AST) enzymes, total serum protein, albumin, urea and creatinine.

In order to evaluate the apparent digestibility (AD) of DM of the rations, the total fecal production of each experimental unit was collected during three consecutive days; a composite sample of the feces was sent for dehydration, and the $\mathrm{AD}$ of the feed was determined by mean of the expression: AD (\%) $=[(\mathrm{g}$ of MS consumed $-\mathrm{g}$ of excreted MS $) \div \mathrm{g}$ of MS consumed] $\times 100$.

At the end of the confinement period, after 12 $\mathrm{h}$ of solids fasting, the animals were weighed and sent to the refrigerator. Slaughter followed the normal flow of the commercial slaughterhouse, in accordance with the laws in force for the slaughter of cattle. In the warm carcasses, the weight was calculated for the return, carcass length, arm length, arm perimeter, thigh thickness and subcutaneous fat thickness at the $12^{\text {th }}$ rib level, according to the methodologies described by Muller (1987). In addition, non-integral body components were weighed.

In order to evaluate the residual depletion of monensin in edible tissues, the 16 animals receiving the ionophore were fed without adding the product for $56 \mathrm{~h}$ (four animals), $32 \mathrm{~h}$ (six animals) and $16 \mathrm{~h}$ (six animals) before slaughter. Fat, muscle, liver and kidney samples were collected during slaughter. Only one animal in the control group had the samples analyzed for calibration purposes for residue detection. These procedures were performed according to recommendations contained in VICH GL48 (2015).

The tissue samples were frozen at $-20{ }^{\circ} \mathrm{C}$ and sent to Quimiplan Análises e Consultoria Ltda. for quantification of monensin by high performance liquid chromatography coupled to sequential mass spectrometry. The limit of quantification (LIQ) was $4 \mu \mathrm{g} \mathrm{kg}^{-1}$ for muscle, liver and kidney, and $12.5 \mu \mathrm{g}$ $\mathrm{kg}^{-1}$ for fat, adequate to respect the recommendations of maximum residue limits (MRLs) in Brazil 
(Brazil, 2008), and those observed in the Japanese Positive List (Japan, 2014) and by Health Canada (Canada, 2017).

For economic analysis, the average regional prices occurring in 2014 were considered, which were: beef cattle at R\$120.29 per @, beef cattle at $\mathrm{R} \$ 4.61$ per $\mathrm{kg}$ live, corn silage at $\mathrm{R} \$ 0.25$ per $\mathrm{kg}$ of $\mathrm{DM}$, concentrated feed mixture at $\mathrm{R} \$ 0.72$ per $\mathrm{kg}$ of DM, and monensin at R\$16.01 per kg of Rumimpex ${ }^{\circledR}$ product.

In the statistical analyses, for data regarding the productive performance in confinement and for the evaluation of serum biochemical profile, the experimental design was completely randomized, in a scheme of plots subdivided by time into three periods of evaluation. The data collected were submitted to analysis of variance with the Tukey test at 5\% significance using the statistical program SAS (1993).

For the parameters related to $\mathrm{AD}$ of the feed, the experimental design was completely randomized, where the stable with two animals was considered by repetition. As for the characteristics of the carcass and non-carcass components, each animal was a repetition. The data collected for each variable were submitted to analysis of variance with a comparison of the average by the F test at 5\% significance, with the statistical program SAS (1993).

Statistical analyses of residual depletion of monensin in tissues were performed according to the model established in the EMEA guide (1996). It recommends that the waiting period and depletion products are traced from linear regression analysis by "Withdrawal-time Calculation Program WT1.4" software, with a $95 \%$ confidence interval. And in order to be able to draw the depletion curve to determine the waiting period, at least three datasets (three restriction times of the active principle before slaughter) are required, at least one set with higher values and one with values below the MRL.

In order to meet the requirements, tests of linearity (F test), homogeneity of variances (Bartlett's test) and normality (Shapiro-Wilk) were performed.

The work was developed after approval of the project by the ethics committee on the use of animals (CEUA/UNICENTRO) under letter no. 002/2014 of March 12 $2^{\text {th }}, 2014$.

A completely randomized design was used, consisting of two treatments with 10 replicates for the control treatment and eight replicates for the treatment with monensin, in a scheme of plots subdivided by time for some variables.

\section{Results and Discussion}

According to Table 2, there was no significant interaction $(\mathrm{P}>0.05)$ between treatments and evaluation periods for $\mathrm{ADG}$, or between confinement treatments for DMI, but for DMI there was a difference $(\mathrm{P}<0.05)$ between periods, showing an increase in consumption by animals. PDMI and $\mathrm{FC}$ presented a difference $(\mathrm{P}<0.05)$ between treatments, demonstrating that the animals treated with monensin showed lower PDMI and better FC. FC, however, worsened over time. This is due to the lower energy efficiency and the metabolism of the animals as maturity progresses, because, according to Owens et al. (1993), the deposition of adipose tissue occurring in later stages requires a greater energetic contribution in relation to the deposition of muscle tissue.

In this experiment, there was a small decrease in DMI for the monensin group, but not significantly different from that for the control group (10.79 vs $11.29 \mathrm{~kg}$ animal $^{-1}$, respectively). PDMI in monensintreated animals decreased by $7 \%(2.36 \%$ vs $2.55 \%)$, with a $14 \%$ improvement in FC (8.61 vs $10.06 \mathrm{~kg}$ $\mathrm{kg}^{-1}$ ) (Table 2), and in feed efficiency $(12.16 \% v s$ $10.84 \%$ ) compared to those fed the control feed, with no significant changes in ADG. Duffield et al. (2012) collected data from 64 studies, including articles and reports on monensin feeding in beef cattle from the last 40 years. They obtained from the compilation of data a decrease in DM consumption 
in the order of $3 \%$, improvement in daily weight gain of $2.5 \%$ and an increase in feed efficiency of $6.4 \%$ when monensin was included in the feed at an average concentration of $28.1 \mathrm{ppm}$, in relation to the control feed. These findings were also verified in the present study, in which the decrease in DMI was $4.43 \%$, the improvement in daily weight gain was $6.71 \%$ and the increase in food efficiency was $10.86 \%$ for monensin treatment, corroborating the data presented by Duffield et al. (2012).
This happens, according to Ladeira et al. (2014), because of changes in the ruminal microbiota which increase the proportion of propionate and alter satiety mechanisms, reducing the amount of food ingested and increasing the frequency of meals, since propionate is oxidized in the liver as a source of energy. The physiological effect of the energy level regulates consumption, and, in this case, an increase in energy efficiency favors the reduction of consumption (FERREIRA AND ALVES, 2016).

Table 2. Effect of monensin on the productive performance of young bulls in confinement.

\begin{tabular}{|c|c|c|c|c|}
\hline \multirow{2}{*}{ Treatment } & \multicolumn{3}{|c|}{ Confinement period (days) } & \multirow{2}{*}{ Average } \\
\hline & $1^{\text {st }}$ period $(0-28)$ & $2^{\text {nd }}$ period $(29-56)$ & $3^{\text {rd }}$ period $(57-84)$ & \\
\hline & \multicolumn{3}{|c|}{ Daily gain of average weight $\left(\mathrm{kg}\right.$ animal $\left.{ }^{-1}\right)$} & \\
\hline Control & 1.266 & 1.230 & 1.175 & $1.224 \mathrm{~A}$ \\
\hline Monensin & 1.371 & 1.290 & 1.275 & $1.312 \mathrm{~A}$ \\
\hline Average & $1.318 \mathrm{a}$ & $1.260 \mathrm{a}$ & $1.225 \mathrm{a}$ & \\
\hline \multicolumn{5}{|c|}{ Daily consumption of dry matter $\left(\mathrm{kg}\right.$ animal $\left.^{-1}\right)$} \\
\hline Control & 10.75 & 11.21 & 11.91 & $11.29 \mathrm{~A}$ \\
\hline Monensin & 10.12 & 10.91 & 11.34 & $10.79 \mathrm{~A}$ \\
\hline Average & $10.43 \mathrm{~b}$ & $11.06 \mathrm{ab}$ & $11.63 \mathrm{a}$ & \\
\hline \multicolumn{5}{|c|}{ Consumption in relation to live weight (\%) } \\
\hline Control & 2.63 & 2.52 & 2.49 & $2.55 \mathrm{~A}$ \\
\hline Monensin & 2.41 & 2.38 & 2.30 & $2.36 \mathrm{~B}$ \\
\hline Average & $2.52 \mathrm{a}$ & $2.45 \mathrm{a}$ & $2.39 \mathrm{a}$ & \\
\hline \multicolumn{5}{|c|}{ Food conversion $\left(\mathrm{kg} \mathrm{kg}^{-1}\right)$} \\
\hline Control & 8.96 & 10.28 & 10.94 & $10.06 \mathrm{~A}$ \\
\hline Monensin & 7.66 & 8.87 & 9.29 & $8.61 \mathrm{~B}$ \\
\hline Average & $8.31 \mathrm{~b}$ & $9.58 \mathrm{ab}$ & $10.11 \mathrm{a}$ & \\
\hline
\end{tabular}

Averages, followed by capital letters, in a column, are different by $\mathrm{F}$ test at $5 \%$.

Averages, followed by lowercase letters, in a row, are different by Tukey test at $5 \%$.

Concomitant with these effects, changes in the ruminal fermentation parameters expected through the effects of monensin promoted an increase $(\mathrm{P}$ $<0.05$ ) of $17 \mathrm{~kg}$ in farm live weight and of $13 \mathrm{~kg}$ in warm carcass weight, in addition to an increase in subcutaneous fat thickness (4.97 vs $4.25 \mathrm{~mm}$ ) (Table 3). 
Table 3. Effect of monensin on the carcass traits of confined finishing young bulls.

\begin{tabular}{lccccc}
\hline \multirow{2}{*}{ Parameter } & \multicolumn{2}{c}{ Treatment } & \multirow{2}{*}{ Average } & \multirow{2}{*}{ Prob. } & \multirow{2}{*}{ CV (\%) } \\
\cline { 2 - 3 } & Monensin & Control & & & \\
\hline Farm live weight $(\mathrm{kg})$ & $511.0 \mathrm{a}$ & $494.0 \mathrm{~b}$ & 502.0 & 0.024 & 2.8 \\
Warm carcass weight $(\mathrm{kg})$ & $285.0 \mathrm{a}$ & $272.0 \mathrm{~b}$ & 278.0 & 0.014 & 3.4 \\
Carcass return (\%) & $55.72 \mathrm{a}$ & $55.03 \mathrm{a}$ & 55.38 & 0.075 & 1.4 \\
Carcass length (m) & $1.28 \mathrm{a}$ & $1.27 \mathrm{a}$ & 1.27 & 0.828 & 1.6 \\
Thigh width (cm) & $22.06 \mathrm{a}$ & $21.63 \mathrm{a}$ & 21.84 & 0.635 & 9.1 \\
Arm width (cm) & $38.53 \mathrm{a}$ & $37.98 \mathrm{a}$ & 38.25 & 0.377 & 3.5 \\
Arm perimeter (cm) & $41.34 \mathrm{a}$ & $41.63 \mathrm{a}$ & 41.48 & 0.747 & 4.6 \\
Fat thickness (mm) & $4.97 \mathrm{a}$ & $4.25 \mathrm{~b}$ & 4.61 & 0.002 & 7.7 \\
\hline
\end{tabular}

Averages, followed by lowercase letters, in a row, are different by $\mathrm{F}$ test at $5 \%$.

Barducci et al. (2013) evaluated young Brangus bulls in a containment system, with sodium monensin supplementation, and also observed higher final weight of supplemented animals in comparison to the control group (475 vs $460 \mathrm{~kg}$ ), higher hot carcass weight (248vs $240 \mathrm{~kg}$ ), and no significant difference for carcass return ( $52 \%$ for both), while Ladeira et al. (2014) obtained higher carcass return (56\% vs $54.5 \%$ ) and higher subcutaneous fat thickness for monensin-treated animals. Such increases can be explained by the increase in metabolizable energy of the feed. According to Oliveira et al. (2007), higher fat deposition may be due to an increase in the total production of short chain fatty acids, concomitant with a reduction in methane production.

In Table 4, it is possible to verify that there was no significant effect of monensin on daily manure production or on $\mathrm{DM}$ AD.

Table 4. Effect of monensin on manure, natural matter (NM) or dry matter (DM) production, and apparent digestibility (AA) of bulls fed diets.

\begin{tabular}{lccccc}
\hline \multirow{2}{*}{ Parameter } & \multicolumn{2}{c}{ Treatment } & \multirow{2}{*}{ Average } & \multirow{2}{*}{ Prob. } & \multirow{2}{*}{ CV (\%) } \\
\cline { 2 - 3 } & Monensin & Control & & & \\
\hline Production of manure (kg day ${ }^{-1}$ of NM) & $15.39 \mathrm{a}$ & $16.98 \mathrm{a}$ & 16.19 & 0.172 & 14.60 \\
Dry matter of manure (\%) & $19.33 \mathrm{a}$ & $19.40 \mathrm{a}$ & 19.37 & 0.783 & 2.84 \\
Production of manure (kg day ${ }^{-1}$ of DM) & $2.98 \mathrm{a}$ & $3.29 \mathrm{a}$ & 3.19 & 0.147 & 13.51 \\
Apparent digestibility (\%) & $72.79 \mathrm{a}$ & $70.69 \mathrm{a}$ & 71.71 & 0.104 & 3.65 \\
\hline
\end{tabular}

Averages, followed by different lowercase letters, in a row, are different by $\mathrm{F}$ test at $5 \%$.

Numerically, the monensin treatment presented higher $\mathrm{AD}(72.79 \%$ vs $70.69 \%)$. Borges et al. (2008) also obtained a non-significant increase in the digestibility coefficient of ruminally cannulated cows of $66.4 \%$ vs $60.4 \%$ for treatment with monensin and control, respectively. Zeoula et al. (2008) found an increase of $8 \%$ in $\mathrm{AD}$ of $\mathrm{DM}$ with the use of monensin, and an increase in total digestibility of CP in the intestine, while Oliveira et al. (2007) did not obtain alterations in the digestibility of DM and 
nutrients for sheep supplemented with monensin. Ionophores regularly have the action of increasing the digestibility of DM and starch in food based on grains, because there is a decrease in food intake; consequently, ruminal microflora have more time for digestion, considering the decrease in the rate of passage (RUSSELL; HOULIHAN, 2003).

The data from the present study also showed that the inclusion of monensin in the feed of confined cattle did not present a statistically significant effect on serum biochemical markers (Table 5) related to renal, inflammatory and hepatic function, proving that the dosage used did not affect the physiological functions of the animals. However, evaluation period had a significant effect on some parameters.

The inference that the inclusion of monensin does not cause inflammatory disorders is evidenced by fibrinogen, the main indicator of acute inflammation in ruminants (KANEKO, 2008), which in all evaluations remained below the reference values.
According to Table 5, the levels of plasma protein, fibrinogen, GGT, urea and creatinine presented a significant change $(\mathrm{P}<0.05)$ according to the evaluation period, independent of monensin treatment. These variables showed changes depending on the age and development of the animal. This alteration is related to changes in metabolism and body composition due to changes in the deposition rate of bone, muscle and adipose tissue until body maturity occurs (OWENS et al., 1993).

Nogueira et al. (2009) reported that excessive dosage of ionophores might lead to an increase in plasma creatine and AST due to the progression of muscle damage, while França et al. (2009) reported cardiac and skeletal lesions in sheep that died due to monensin sodium poisoning. There was no increase in these serum parameters during the evaluation, which indicates use of a dosage that does not impair animal musculoskeletal metabolism.

Table 5. Effect of monensin on serum biochemical markers related to hepatic, inflammatory and renal function of confined young bulls, according to evaluation days.

\begin{tabular}{|c|c|c|c|c|c|}
\hline \multirow{2}{*}{ Treatment } & \multicolumn{4}{|c|}{ Evaluation period } & \multirow{2}{*}{ Reference value $^{1}$} \\
\hline & Day 0 & Day 28 & Day 56 & Day 84 & \\
\hline \multicolumn{6}{|c|}{ Plasma protein $\left(\mathrm{g} \mathrm{dL}^{-1}\right)$} \\
\hline Control & $8.05 \pm 0.6$ & $6.87 \pm 0.5$ & $8.12 \pm 0.9$ & $8.8 \pm 0.6$ & \multirow{2}{*}{$6.97-8.85$} \\
\hline Monensin & $8.18 \pm 0.6$ & $6.99 \pm 0.4$ & $7.87 \pm 1.0$ & $8.74 \pm 0.6$ & \\
\hline Additive effect $(\mathrm{M})^{2}$ & \multicolumn{4}{|c|}{ Prob $>F=0.5190$} & \multirow{5}{*}{$2.82-3.55$} \\
\hline Effect period $(\mathrm{P})^{2}$ & \multicolumn{4}{|c|}{ Prob $>F=0.003$} & \\
\hline Interaction $\mathrm{M}^{*} \mathrm{P}^{2}$ & \multicolumn{4}{|c|}{ Prob $>F=0.7342$} & \\
\hline \multicolumn{6}{|c|}{ Albumin $\left(\mathrm{mg} \mathrm{dL}^{-1}\right)$} \\
\hline Control & $4.51 \pm 0.4$ & $4.34 \pm 0.2$ & $4.19 \pm 0.6$ & $4.15 \pm 0.3$ & \\
\hline Monensin & $4.58 \pm 0.3$ & $4.48 \pm 0.2$ & $4.28 \pm 0.5$ & $4.24 \pm 0.1$ & \\
\hline Additive effect $(\mathrm{M})^{2}$ & \multicolumn{4}{|c|}{ Prob $>F=0.3641$} & \\
\hline Effect period $(\mathrm{P})^{2}$ & \multicolumn{4}{|c|}{ Prob $>F=0.1061$} & \\
\hline Interaction $\mathrm{M}^{*} \mathrm{P}^{2}$ & \multicolumn{4}{|c|}{ Prob $>F=0.9875$} & \\
\hline
\end{tabular}


continuation

\begin{tabular}{|c|c|c|c|c|c|}
\hline \multicolumn{6}{|c|}{ Plasma fibrinogen $\left(\mathrm{g} \mathrm{dL}^{-1}\right)$} \\
\hline Control & $0.64 \pm 0.1$ & $0.42 \pm 0.2$ & $0.34 \pm 0.2$ & $0.84 \pm 0.3$ & \multirow{2}{*}{$300-700$} \\
\hline Monensin & $0.60 \pm 0.2$ & $0.50 \pm 0.2$ & $0.30 \pm 0.2$ & $0.68 \pm 0.3$ & \\
\hline Additive effect $(\mathrm{M})^{2}$ & \multicolumn{4}{|c|}{ Prob $>F=0.5190$} & \\
\hline Effect period $(\mathrm{P})^{2}$ & \multicolumn{4}{|c|}{ Prob $>F=0.0003$} & \\
\hline Interaction $\mathrm{M}^{*} \mathrm{P}^{2}$ & \multicolumn{4}{|c|}{ Prob $>F=0.4683$} & \\
\hline \multicolumn{6}{|c|}{ Aspartate aminotransferase (AST UI L ${ }^{-1}$ ) } \\
\hline Control & $61.1 \pm 12.7$ & $74.6 \pm 19.7$ & $87.8 \pm 30.7$ & $69.7 \pm 11.9$ & \multirow{2}{*}{$47.9-89.4$} \\
\hline Monensin & $76.7 \pm 25.6$ & $76.9 \pm 13.1$ & $80.2 \pm 27.1$ & $81.4 \pm 18.2$ & \\
\hline Additive effect $(\mathrm{M})^{2}$ & \multicolumn{4}{|c|}{ Prob $>F=0.3529$} & \\
\hline Effect period $(\mathrm{P})^{2}$ & \multicolumn{4}{|c|}{ Prob $>F=0.1153$} & \\
\hline Interaction $\mathrm{M}^{*} \mathrm{P}^{2}$ & \multicolumn{4}{|c|}{ Prob $>F=0.4648$} & \\
\hline \multicolumn{6}{|c|}{ Glutamyl transferase range (GGT UI L ${ }^{-1}$ ) } \\
\hline Control & $8.6 \pm 3.3$ & $17.8 \pm 3.4$ & $15.1 \pm 5.4$ & $13.9 \pm 7.2$ & \multirow{2}{*}{$9.2-24.3$} \\
\hline Monensin & $7.5 \pm 3.2$ & $19.0 \pm 4.4$ & $12.2 \pm 5.5$ & $10.9 \pm 5.0$ & \\
\hline Additive effect $(\mathrm{M})^{2}$ & \multicolumn{4}{|c|}{ Prob $>F=0.2879$} & \\
\hline Effect period $(\mathrm{P})^{2}$ & \multicolumn{4}{|c|}{ Prob $>F=0.0032$} & \\
\hline Interaction $\mathrm{M}^{*} \mathrm{P}^{2}$ & \multicolumn{4}{|c|}{ Prob $>F=0.6589$} & \\
\hline \multicolumn{5}{|c|}{ Urea $\left(\mathrm{mg} \mathrm{dL}^{-1}\right)$} & \multirow{3}{*}{$28.7-48.8$} \\
\hline Control & $19.3 \pm 4.6$ & $24.1 \pm 5.5$ & $35.0 \pm 8.5$ & $33.9 \pm 6.6$ & \\
\hline Monensin & $19.9 \pm 5.3$ & $23.8 \pm 2.1$ & $31.9 \pm 8.3$ & $33.7 \pm 4.6$ & \\
\hline Additive effect $(\mathrm{M})^{2}$ & \multicolumn{4}{|c|}{ Prob $>F=0.7211$} & \\
\hline Effect period $(\mathrm{P})^{2}$ & \multicolumn{4}{|c|}{ Prob $>\mathrm{F}=<0.0001$} & \\
\hline Interaction $\mathrm{M}^{*} \mathrm{P}^{2}$ & \multicolumn{4}{|c|}{ Prob $>F=0.6616$} & \\
\hline \multicolumn{6}{|c|}{ Creatinine $\left(\mathrm{mg} \mathrm{dL}^{-1}\right)$} \\
\hline Control & $1.10 \pm 0.3$ & $1.62 \pm 0.5$ & $1.60 \pm 0.4$ & $1.58 \pm 0.2$ & \multirow{2}{*}{$1.08-1.88$} \\
\hline Monensin & $1.18 \pm 0.3$ & $1.64 \pm 0.2$ & $1.38 \pm 0.2$ & $1.70 \pm 0.2$ & \\
\hline Additive effect $(\mathrm{M})^{2}$ & \multicolumn{4}{|c|}{ Prob $>F=0.8162$} & \\
\hline Effect period $(\mathrm{P})^{2}$ & \multicolumn{4}{|c|}{ Prob $>\mathrm{F}=<0.0001$} & \\
\hline Interaction $\mathrm{M}^{*} \mathrm{P}^{2}$ & \multicolumn{4}{|c|}{ Prob $>F=0.1651$} & \\
\hline
\end{tabular}

${ }^{1}$ Adapted from: Kaneko (2008); Lopes, Biondo and Santos (2007); Cardoso et al. (2011).

${ }^{2}$ Values of Prob $>$ F related to multivariate analysis of variance (MANOVA; P < 0.05).

According to Table 6, no monensin residues were detected in the animal tissue samples, regardless of the waiting period. The concentrations of monensin obtained in different animal tissues (muscle, fat, liver and kidney) after 16, 32 and $56 \mathrm{~h}$ of product suppression prior to slaughter of animals (grace period) were lower than the residual ceilings imposed by the Japanese Positive List (2014), Codex Alimentarius (2014) and Normative Instruction $\mathrm{N}^{\mathrm{o}} 10$ of BRASIL (2008). According to Donoho (1984), even in intoxicated animals, the concentrations of monensin in blood and tissue are relatively low. 
Table 6. Concentration of monensin in bovine tissues after different periods between suspension of consumption of the product and slaughter of animals (waiting period).

\begin{tabular}{|c|c|c|c|c|c|c|c|}
\hline \multirow[t]{2}{*}{ Tissue } & \multicolumn{3}{|c|}{ Recommended residual maximum limit (RML) } & \multirow[t]{2}{*}{$\mathrm{LIQ}^{4}$} & \multicolumn{3}{|c|}{$\begin{array}{l}\text { Concentration of monensin according } \\
\text { to the waiting period }\end{array}$} \\
\hline & $\mathrm{LPJ}^{1}$ & CODEX $^{2}$ & IN N $13^{3}$ & & $56 \mathrm{~h}$ & $32 \mathrm{~h}$ & $16 \mathrm{~h}$ \\
\hline & \multicolumn{7}{|c|}{$\left(\mu \mathrm{g} \mathrm{kg}^{-1}\right)$} \\
\hline Muscle & 50 & 10 & - & 4 & $<1.0$ & $<1.0$ & $<1.0$ \\
\hline Fat & 50 & 100 & - & 12.5 & $<5.0$ & $<5.0$ & $<5.0$ \\
\hline Liver & 50 & 100 & 20 & 4 & $<5.0$ & $<5.0$ & $<5.0$ \\
\hline Kidney & 50 & 10 & - & 4 & $<5.0$ & $<5.0$ & $<5.0$ \\
\hline
\end{tabular}

${ }^{1}$ Source: Japanese Positive List (CODEX) (2014).

${ }^{2}$ Source: Codex Alimentarius (2014).

${ }^{3}$ Source: Normative Instruction $\mathrm{N}^{\mathrm{o}} 10$ (2008).

${ }^{4}$ The limit of quantification (LIQ) must correspond to at most half of the lowest RML established for each tissue.

Donoho (1984) describes the use of $30 \mathrm{ppm}$ of monensin in bovine feed, with a waiting period for slaughter equivalent to $12 \mathrm{~h}$ from the last administration to analysis of the tissue concentration. The results obtained by the author indicate concentrations in muscle, kidney and fat lower than $0.025 \mathrm{ppm}$, and in the liver varying from 0.21 to $0.59 \mathrm{ppm}$. These results are considerably lower than those obtained in dogs and extrapolated to humans deemed to cause slight changes in coronary blood flow ( $0.69 \mathrm{mg} \mathrm{kg}^{-1}$ of body weight), demonstrating the impossibility of disturbances caused by the intake of products from animals fed with monensin.

In addition, human resistance to antibiotics is related to the use of ionophores in ruminants, but Russell and Houlihan (2003) point out that there is no interconnection since they are not used for treatment of human diseases. Thus, the use of ionophores in animal feed is not likely to impact the transfer of resistance to antibiotics from animal to man, since the concentrations used are insufficient to result in residues and to influence human health (DONOHO, 1984).

As for non-carcass components (Table 7), these were not altered $(\mathrm{P}>0.05)$ by the addition of monensin to the feed. No significant differences were observed in treatments regarding the carcass return, so it is suggested that the organs represent the same proportion of the empty body (LADEIRA et al., 2014). Furthermore, the use of monensin at an appropriate dose did not compromise the anatomical structure of any organ, confirming the safety of its use in ruminant feeding.

In Table 8, it is possible to observe that the use of monensin for finishing cattle promoted an increase of $\mathrm{R} \$ 122.84$ in the profit margin per animal, and the animals not treated with monensin caused losses to the producer. This is explained possibly by the reduction of PDMI, and improved FC, which reduces the cost per $\mathrm{kg}$ of gain of animals supplemented with monensin.

According to Russell and Houlihan (2003), the improvement in growth and efficiency in animal production with the use of antibiotics as performance improvers is less than $10 \%$, but the economic benefit of use may be as large as the profit margin of production. This fact can be verified by the present experiment, in which the profit obtained was due to use of monensin sodium. 
Table 7. Effect of monensin on the non-integral components of the carcass of finished young bulls in confinement.

\begin{tabular}{lccccc}
\hline \multirow{2}{*}{ Parameter (kg) } & \multicolumn{2}{c}{ Treatment } & Average & Prob. & \multirow{2}{*}{ CV (\%) } \\
\cline { 2 - 3 } & Monensin & Control & & & \\
\hline Heart & $1.72 \mathrm{a}$ & $1.71 \mathrm{a}$ & 1.71 & 0.775 & 6.6 \\
Liver & $5.35 \mathrm{a}$ & $5.50 \mathrm{a}$ & 5.43 & 0.446 & 7.9 \\
Lungs & $4.22 \mathrm{a}$ & $4.44 \mathrm{a}$ & 4.33 & 0.251 & 9.2 \\
Kidneys & $0.96 \mathrm{a}$ & $1.00 \mathrm{a}$ & 0.98 & 0.395 & 10.7 \\
Spleen & $1.86 \mathrm{a}$ & $1.50 \mathrm{a}$ & 1.68 & 0.060 & 18.9 \\
Full rumen/reticle & $43.33 \mathrm{a}$ & $41.90 \mathrm{a}$ & 42.61 & 0.419 & 8.8 \\
Empty rumen/reticle & $8.29 \mathrm{a}$ & $8.19 \mathrm{a}$ & 8.24 & 0.703 & 6.9 \\
Full abomasum & $4.81 \mathrm{a}$ & $4.61 \mathrm{a}$ & 4.71 & 0.484 & 13.1 \\
Empty abomasom & $4.00 \mathrm{a}$ & $4.13 \mathrm{a}$ & 4.06 & 0.608 & 13.3 \\
Full intestines & $30.94 \mathrm{a}$ & $31.64 \mathrm{a}$ & 31.29 & 0.592 & 9.0 \\
Head & $12.66 \mathrm{a}$ & $12.24 \mathrm{a}$ & 12.45 & 0.174 & 4.9 \\
Tongue & $0.92 \mathrm{a}$ & $0.91 \mathrm{a}$ & 0.91 & 0.625 & 7.2 \\
Leather & $47.22 \mathrm{a}$ & $44.65 \mathrm{a}$ & 45.93 & 0.059 & 4.4 \\
Tail & $1.53 \mathrm{a}$ & $1.45 \mathrm{a}$ & 1.49 & 0.373 & 13.2 \\
Paw & $10.97 \mathrm{a}$ & $10.95 \mathrm{a}$ & 10.96 & 0.958 & 6.4 \\
\hline
\end{tabular}

Averages, followed by lowercase letters, in a row, are different by $\mathrm{F}$ test at $5 \%$.

Table 8. Economic analysis of the addition of monensin to finishing rations of confined bulls.

\begin{tabular}{lcc}
\hline \multirow{2}{*}{ Parameter (R per animal) } & \multicolumn{2}{c}{ Treatment } \\
\cline { 2 - 3 } & Monensin & Control \\
\hline Daily cost of food & 5.21 & 5.45 \\
Daily cost with monensin & 0.02 & 0.00 \\
Total food cost in the period & 439.20 & 457.79 \\
Cost of lean cattle & 1.738 .39 & 1.738 .39 \\
Gross revenue & 2.285 .51 & 2.181 .26 \\
Profit margin & 107.92 & -14.92 \\
\hline
\end{tabular}

\section{Conclusion}

The inclusion of monensin in feed favored the performance in confinement of young bulls, reducing DM intake and improving $\mathrm{FC}$, these being determinant factors to guarantee the profit margin of the activity. 


\section{References}

BARDUCCI, R. S.; SARTI, L. M.; MILLEN, D. D.; PACHECO, R. D. L.; BALDIN, S. R.; PARRA, F. S.; PUTAROV, T. C.; MARTINS, C. L.; ARRIGONI, M. D. B. Aditivos alimentares na dieta de bovinos confinados. Arquivo Brasileiro de Medicina Veterinária e Zootecnia, Belo Horizonte, v. 65, n. 6, p. 1593-1602, 2013.

BORGES, L. F. O.; PASSANI, R.; MEYER, P. M.; RODRIGUES, P. H. M. Efeitos da enramicina e monensina sódica sobre a digestão de nutrientes em bovinos alimentados com dietas contendo alto nível de concentrados. Revista Brasileira de Zootecnia, Viçosa, v. 37, n. 4, p. 674-680, 2008.

BRASIL. Ministério da Agricultura Pecuária e Abastecimento. Instrução Normativa $n^{\circ} 10$, de 14 de abril de 2008. Aprova os programas de controles de resíduos e contaminantes em carnes (bovina, aves, suína e eqüina), leite, mel, ovos e pescado. Brasília, 2008. 3 p.

CANADA. Health Canada. List of Maximum Residue Limits (MRLs) for Veterinary Drugs in Foods. Ottawa: Health Canada. 2017. 28 p.

CARDOSO, D.; COSTA, M. F. O.; BENATTI, L. A. T.; LAUDARES, K. M.; VAZ JUNIOR, R. G.; FIORAVANTI, M. C. S. Perfil Bioquímico de Bovinos de raças localmente adaptadas em sistema intensivo de criação. In: SEMINÁRIO DE INICIAÇÃO CIENTÍFICA DA UFG, 19., 2011, Goiás. Anais... Goiás: Universidade Federal de Goiás, 2011. p. 1-12.

DONOHO, A. L. Biochemical studies on the fate of monensin in animals and in the environment. Journal of Animal Science, Champaign, v. 58, n. 6, p. 1528-1539, 1984.

DUFFIELD, T. F.; MERRILL, J. K.; BAGG, R. N. Metaanalysis of the effects of monensin in beef cattle on feed efficiency, body weight, and dry matter intake. Journal of Animal Science, Champaign, v. 90, n. 12, p. 4583-4592, 2012.

EMEA - The European Agency for the Evaluation of Medicinal Products / Committee for Veterinary Medicinal Products. Note for guidance: Approach towards harmonization of withdrawal periods. London, 1996.

FERREIRA, A. F. A.; ALVES, T. P. Utilização de monensina sódica para bovinos de corte a pasto. Investigação, Franca, v. 15, n. 7, p. 37-42, 2016.

FRANÇA, T. N.; NOGUEIRA, V. A.; YAMASAKI, E. M.; CALDAS, S. A.; TOKARNIA, C. H.; PEIXOTO, P. V. Intoxicação acidental por monensina em ovinos no estado do Rio de Janeiro. Pesquisa Veterinária Brasileira, Rio de Janeiro, v. 29, n. 9, p. 743-746, 2009.
GATTÁS, G.; FERREIRA, A. S.; BARBOSA, F. F. Níveis de plasma sangüíneo em pó em dietas para leitões desmamados aos 14 dias de idade. Revista Brasileira de Zootecnia, Viçosa, v. 37, n. 2, p. 278-285, 2008.

JAPAN. Ministry of Health, Labour and Welfare. The maximum residue limits of substances used as ingredients of agricultural chemicals in foods. Tokyo: Ministry of Health, Labour and Welfare Editora. 2014. 1045 p.

KANEKO, J. J. Clinical biochemistry of domestic animals. 6. ed. San Diego: Elsevier, 2008. 905 p.

KOBAYASHI, Y. Abatement of methane production from ruminants: trends in the manipulation of rumen fermentation. Asian-Australasian Journal of Animal Science, Seoul, v. 23, n. 3, p. 410-416, 2010.

LADEIRA, M. M.; NETO, O. R. M.; SANTAROSA, L. C.; CHIZZOTTI, M. L.; OLIVEIRA, D. M.; CARVALHO, J. R. R.; ALVES, M. C. L. Desempenho, características de carcaça e expressão de genes em tourinhos alimentados com lipídeos e monensina. Pesquisa Agropecuária Brasileira, Brasília, v. 49, n. 9, p. 728-736, 2014.

LOPES, S. T. A.; BIONDO, A. W.; SANTOS, A. P. Manual de patologia clínica veterinária. 3. ed. Santa Maria: UFSM, 2007. 107 p.

MILLEN, D. D.; PACHECO, R. D. L.; ARRIGONI, M. D. B.; GALYEAN, M. L.; VASCONCELOS, J. T. A snapshot of management practices and nutritional recommendations used by feedlot nutritionists in Brazil. Journal of Animal Science, Champaign, v. 87, n. 10, p. 3427-3439, 2009.

MULLER, L. Normas para avaliação de carcaça e concurso de carcaças de novilhos. 2. ed. Santa Maria: UFSM, 1987. 31 p.

NOGUEIRA, V. A.; FRANÇA, T. N.; PEIXOTO, P. $\mathrm{V}$. Intoxicação por antibióticos ionóforos em animais. Pesquisa Veterinária Brasileira, Rio de Janeiro, v. 29, n. 3, p. 191-197, 2009.

NATIONAL RESEARCH COUNCIL. - NRC. Nutrient requirements of beef cattle.7. ed. Washington: National Academy of Sciences, 2000. 248 p.

OLIVEIRA, M. V. M.; LANA, R. P.; EIFERT, E. C.; LUZ, D. F.; PEREIRA, J. C.; PÉREZ, J. R. O.; VARGAS JUNIOR, F. M. Influência da monensina sódica no consumo e na digestibilidade de dietas com diferentes teores de proteína para ovinos. Revista Brasileira de Zootecnia, Viçosa, v. 36, n. 3, p. 643-651, 2007.

OWENS, F. N.; DUBESKI, P.; HANSON, C. F. Factors that alter the growth and development of ruminants. Journal of Animal Science, Champaign, v. 71, n. 11, p. 31-38, 1993. 
PRADO, O. P. P.; ZEOULA, L. M.; MOURA, L. P. P.; FRANCO, S. L.; PRADO, I. N.; GOMES, H. C. C. Digestibilidade e parâmetros ruminais de dietas à base de forragem com adição de própolis e monensina sódica para bovinos. Revista Brasileira de Zootecnia, Viçosa, v. 39, n. 6, p. 1336-1345, 2010.

RANGEL, A. H. N.; LEONEL, F. P.; SIMPLÍCIO, A. A.; MENDONÇA JÚNIOR, A. F. Utilização de ionóforos na produção de ruminantes. Revista de Biologia e Ciências da Terra, Aracaju, v. 8, n. 2, p. 173-182, 2008.

RUSSELL, J. B.; HOULIHAN, A. J. Ionophore resistance of ruminal bacteria and its potential impact on human health. FEMS Microbiology Reviews, Amsterdam, v. 27, n. 1, p. 65-74, 2003.

STATISTICAL ANALYSIS SYSTEM INSTITUTE SAS Institute. SAS/STAT user's Guide: statistics, version 6. 4. ed. Cary: SAS Institute, 1993. v. 2, 943 p.

SILVA, D. J.; QUEIROZ, A. C. Análise de alimentos: métodos químicos e biológicos. 3. ed. Viçosa-MG: UFV, 2009. 235 p.
VICHGL48-InternationalCooperation on Harmonization of Technical Requirements for Registration of Veterinary Medicinal Products. Studies to evaluate the metabolism and residue kinetics of veterinary drugs in food-producing animals: Marker residue depletion studies to establish product withdrawal periods. Rockville: MD, 2015.

WEISS, W. P.; CONRAD, H. R.; ST. PIERRE, N. R. A theoretically based model for predicting total digestible nutrient values of forages and concentrates. Animal Feed Science and Technology, Amsterdam, v. 39, n. 1, p. 95110, 1992.

ZANINE, A. M.; OLIVEIRA, J. S.; SANTOS, E. M. Importância, uso, mecanismo de ação e retorno econômico dos ionóforos na nutrição de ruminantes. Revista Científica Eletrônica de Medicina Veterinária, Garça, v. 6, n. 1, p.1-18, 2006.

ZEOULA, L. M.; BELEZE, J. R. F.; GERON, L. J. V.; MAEDA, E. M.; PRADO, I. N.; PAULA, M. C. Digestibilidade parcial e total de rações com a inclusão de ionóforo ou probiótico para bubalinos e bovinos. Revista Brasileira de Zootecnia, Viçosa, v. 37, n. 3, p. 563-571, 2008. 
